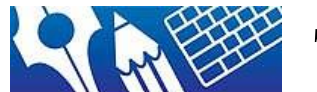

Australasian Association of Writing

Programs

\section{TEXT SPECIAL ISSUES}

Number 62 October 2021

ISSN: 1327-9556 | https://textjournal.scholasticahq.com/

\title{
Writing and performing Barbara and the Camp Dogs
}

\section{Ursula Yovich in conversation with Alana Valentine}

To cite this article: Yovich, U. in conversation with Alana Valentine (2021). Writing and performing Barbara and the Camp Dogs. In F. Collins, H. Joyce and N. Maloney (Eds.) The Place of Writing in Intercultural and Intermedial Creative Collaborations. TEXT Special Issue 62. 


\title{
Writing and performing Barbara and the Camp Dogs
}

\section{Speakers: Ursula Yovich in conversation with Alana Valentine}

\section{Chair: Felicity Collins}

\begin{abstract}
:
This is the edited transcript of Session 1 of the Symposium on Creative Collaborations in Intercultural and Intermedial Spaces, convened by Creative Arts and English, La Trobe University, 7-9 July 2020. The three-day symposium opened with Ursula Yovich and Alana Valentine in conversation about their award-winning collaboration on the high-octane, pub-gig, rock-musical, road-trip, stage-show Barbara and the camp dogs, winner of four Helpmann awards in 2019 and four Green Room awards in 2020.

Biographical note:

Ursula Yovich is a writer, singer, and actor who grew up in Darwin and Maningrida. She has performed on stage and screen in a wide range of highly acclaimed and award-winning productions. In 2016, she won the Balnaves Foundation Indigenous Playwright's Award. Her stage credits include The sapphires, Diving for pearls, Heart is a wasteland, The secret river, Mother Courage and her children, Walk a mile in my shoes, and Waltzing the wilarra. Her cabaret show, Magpie blues, toured Australia and was nominated for a Helpmann award. Her film credits include Australia, Jindabyne, and Top end wedding. Television credits include The code, Redfern now, Rake, The gods of Wheat St, Murundak: Songs of freedom, Blue heelers, Songlines, and Mystery road. In 2019, Ursula won the Helpmann Award for Best Female Actor in a Musical for Barbara and the camp dogs, which also won Best Musical. In 2020, Ursula delivered the inaugural NIDA NAIDOC Week Lecture, asking why diversity in the arts is still an 'uphill battle' in Australia.
\end{abstract}

Alana Valentine is a writer, director, and dramaturg who grew up in Sydney and is best known for her contributions to verbatim and close work theatre, including Run rabbit run (2004), Parramatta girls (2007), Shafana and Aunt Sarrinah (2010), and Ladies day (2016). She is the author of Bowerbird: The art of making theatre drawn from life (2018). She worked with Ursula Yovich and producer Vicki Gordon as writer/director of Barefoot divas (touring from 20122015 in Australia, North America, Canada, and Hong Kong) and as co-writer/songwriter with Ursula Yovich on the multi-award winning, Barbara and the camp dogs. As a dramaturg, Alana has worked with Bangarra Dance Theatre's artistic director Stephen Page on Patyegarang, ID, Bennelong, and Dark emu. In 2019, Alana shared the Helpmann Award for Best Musical Score with Ursula Yovich and Adm Ventoura for Barbara and the camp dogs.

Keywords:

Co-writing for performance, performing the angry black woman, collaboration as play 
Felicity: Thank you everyone for coming today for the opening session of our symposium on intercultural and intermedial collaboration. I would like to begin by acknowledging the traditional owners of the lands on which we are meeting today, across Australia, via Zoom. Mindful of Megan Davies's recent critique of routine acknowledgments of country by nonIndigenous Australians, I would also like to express support for the recommendations of the 2017 Uluru statement from the heart - calling for a constitutionally enshrined Indigenous voice to Parliament, and a Makaratta for treaty making and truth telling. I hope that in some small way, our opening session on intercultural creative collaboration, might be considered a response to the invitation from Uluru to 'walk with us' towards a better future. This morning it is my great pleasure to welcome our two speakers, Ursula Yovich and Alana Valentine.

[Participants on Zoom were invited by Alana Valentine to introduce themselves before the conversation with Ursula Yovich, transcribed below, began].

Alana: Do you want to start, Urs?

Ursula: I should start with the fact that Barbara is an alter-ego - from being 'good girl Ursula' for so much of my life. Barbara raised me to take on a character to enable me to push back at the things that happened in my life. She's ultimately a reactionary type of character! She was also an in-joke between us - Ningali Lawford was also a Barbara - there were a few of us Barbaras! She came from a silly interaction between Stephen Page [artistic director of Bangarra Dance Theatre] and myself. One day he was there, and it was so organic: 'Why don't we create a show around the character!'

Alana: I just wanted to thank everybody for the introduction. It's really useful for us to know who you are. And I would also like to know who has actually seen Barbara and the camp dogs? I know that you have Felicity; that's great. We're going to show some of it today. First, I want to check, Ursula, have you got enough water? [laughter] So, when we did Barbara and the camp dogs we wrote an introduction for the stage play [holds up book of the script by Yovich and Valentine, published by Currency Press in 2017]. This is the published version of the stage play if you want to pick it up. In it, we talk about how Ursula was a Helpmann award winner - you won for Capricornia, wasn't it, Urs?

Ursula: Yes, 2007.

Alana: And the next year I was nominated for a Helpmann Award for Parramatta girls. And I didn't win. And there's an afterparty - after the Helpmanns. It's funny because in the program note we talk about the fact that I was sitting on a couch - and we have a discussion about whether I was sulking or not - and Ursula comes over to do Barbara. It made very good copy for the [program] note, but I have been reflecting on it as we've been asked to talk about this collaboration, and I want to say that I think that's the first instance I had of Ursula's sensitivity to when people are in a state of vulnerability. When you're at an afterparty you're not saying that you regret that you didn't win! Of course, you're being collegiate and lovely. It's 
interesting for me to reflect on that because we made a bit of a joke about it in the program note. As Ursula said, she performed Barbara at the afterparty, and she'd had a conversation with Vicki Gordon and Stephen Page who said that we should do a show called Barbara and the camp dogs.

Hey Urs, do you remember on opening night, who said that they thought that The camp dogs [the band] were like gay dogs, and that they didn't know what camp dogs were? [laughter]

Ursula: I Ioved that. There is that play on words. You've got your camp dogs - if you've gone out bush there's these wild dogs that actually don't belong to anybody; they just belong to the community. But also, yeah, 'camp'. You talk about 'queer magic' and [pause] I can't even remember myself [laughter].

Alana: Oh, 'black pepper' and 'queer glitter' - we talk about that being lovely.

Ursula: Yeah.

Alana: When we received the Helpmann awards, I stood up and said that we'd always talked about how the collaboration was 'a bit of black pepper', a phrase that Leah Purcell uses about a lot of Indigenous writing. Do you want to expand on 'black pepper', Urs?

Ursula: Oh, jeez, I wish Leah was here. I can't remember what she was saying, to be honest. I can't expand on that, Alana. I can't remember that conversation with her.

Alana: It's to do with a bit of 'edge'. So maybe Ursula you could talk about being 'good girl Ursula'. Can you expand on that and tell them about the rage that sat underneath? I've described Barbara in a very congenial way, and talked about her identifying vulnerability, but Barbara's also got a real darkness.

Ursula: Barbara's got this real darkness. I think I was able to tap into a lot of the stuff that I myself, Ursula, was feeling. And we, Alana and I, both tapped into this when we were doing the Barefoot divas show, Walk a mile in my shoes (Vicki Gordon Music Productions, 20122015). That show had wonderful musicians up on stage, wonderful women sharing our stories as First Nations women. Up until that moment, I'd never been able to voice the things that were going on in my spirit and in my head - just my heart. Walk a mile in my shoes was the first time I was able to sit down and say to Alana, 'these are the things I want to say'. And, Alana, being a wonderful writer, was able to take on what I was saying - taking my words and adding that 'Alana queer glitter magic'. I remember I felt quite strong, even though what I was voicing at the time was this anger that sits under the surface. I had been quite angry for many years as a performer, finding that I was stereotyped, in a sense, as just an Aboriginal actor. That's why I did a monologue in Divas. It was wonderful to go, 'Hey, we are these amazing artists, and we are smashed constantly'. Television, movies, ads are very white-washed stories. That's ok - if there's room for more! Because what we see is not actually representative of what's out there in real life. So, it was through that underlying anger that we were able to begin the journey of writing Barbara. 
Alana: Yeah, that's a great example. For those of you who didn't see Walk a mile in my shoes, the Divas were six First Nations women: two Indigenous Australians, Ursula Yovich and Emma Donovan (a Gumbaingirr woman); three Maori performers, Whirimako Black, Maisey Rika, and Merenia; and a Papua-New Guinean Australian, Ngaire. It was an amazing show where I was recording and listening to these stories. And it's a good example of how Urs and I have continued to work.

People talk about Barbara and the camp dogs as being Ursula's first play, and in a sense it is. But her instincts as a performer and a theatre-maker come from twenty years or more experience. Is it more, Urs? I wouldn't want to own to more than that [laughter].

What was interesting about that first collaboration is that Ursula was saying what she wanted to say, and then as a writer I used my knowledge to shape it, and then feed it back to her so that she could perform it. You might want to talk, Urs, about the difference between writing and performing? Because in a sense you have to almost become another person again when you're performing Barbara. People say, 'Oh well, you wrote it so it's just coming out of that'. But it takes four or five weeks to actually lock in how the performance works.

Ursula: Absolutely. Look, I write songs outside of Barbara and I cannot remember them. So you need that rehearsal time. I've always been wonderful at storytelling and that's definitely my gift [laughter] - something I picked up from my father. But being able to sit there closely with the work, writing it, is such a different headspace, putting this writer frame over yourself. I'm looking at the script as if I'm seeing it for the first time. So, sometimes what you're writing is not going to actually work, because when I'm performing it, the rhythm is not quite right. That rarely happened though, with Barbara, because - I don't know Alana - we did seven years on it, I think, all up. So, with feedback from actors, we had it quite tight by the time we got into the rehearsal space. I don't know if that's answering the question?

Alana: That's exactly it. You'd spent years performing other people's stuff but now you're performing your words. They've been massaged into this collaboration, but they came from you. They were your words. It might be a good time to see part of Ursula's performance in Barbara and the camp dogs, unless you want to say anything before that, Urs?

Ursula: I just want to say, Alana, the first time we had a readback we had the Diva's stuff, and I said, 'Oh, is that how many times I say um and ah'. When you're actually having a conversation with somebody you're a lot more relaxed and your thought processes are a bit all over the place. So, the massaging of that [the words] was interesting. I didn't realise I spoke like that, but obviously I do. It was interesting to be able to sit down and go, 'Oh, I like this'. This process of 'whatever I'm talking about here' [in the script] 'we need to build on that a bit more'. There was a bit of that going on.

Alana: Can we see the opening of Barbara and the camp dogs?

[Video recording: Barbara and her sister Rene sing Look at the sun, then introduce the idea of the angry black woman] 
Alana: What we could talk about, now, is the collaboration on the song-writing, Urs. But before we do that, as this is a seminar about collaboration, I want to talk about how resistant some people are to collaboration in the arts. It's interesting to me that on the opening night of Barbara and the camp dogs, somebody came up to me in the foyer and said, 'This bit in the play, this moment in the play, you wrote that, didn't you?' And I said, 'Well no, we both wrote it.' And they said, 'No, but you wrote it'. And I said, 'No, we both wrote it.' And they had this very irritated look on their face - like, 'Why won't you tell me who did which bit?'

I don't know if it's true for you, Ursula, but getting close to opening night there were emails going back and forth and some were like, 'Oh Alana, can you just change this bit because Ursula's in rehearsal'. And I'd say, 'No, I can't because we're both writing this.' And Urs would be in rehearsal and someone would say, 'Well, can you just change that line?' and Ursula would say, 'Well no, we have to check with Alana'. People found that hard, but they got used to it. And then they stopped asking. One of the things I'm really proud of, that's worked for us, is that there's a real collaboration in how we work. We wrote all of it together as far as I'm concerned. I talk about there being two brains and one keyboard. That's really worked for us. I don't know if you want to talk about that, Ursula?

Ursula: Absolutely. It was difficult, at times, when I was being asked to change things as we were rehearsing. Obviously, at that point I don't have my writer's brain on. But we worked out a great system where this wonderful secondment student, by the name of Riley Spadaro, would write the line that we were thinking of changing and at the end of the day whatever we had discussed he would send on to Alana. So, it worked out great like that. He knew I'd go, 'Write it down for Alana, make sure it's sent off'. It's definitely a collaboration. The moment you start to change things without consulting your co-writer, you know you'll come across a lot of friction. It worked for us and it didn't slow the process up at all. It meant that everyone had to understand that was the way we worked. And we did, at times, share one laptop [laughter]. There were times in our initial rehearsals when we would pass the laptop along. We would even Google documents back and forth to each other.

At the moment, we're writing a final draft where we swap and talk to each other over the phone as we're writing. We discuss the scenes and if something's not quite gelling with me, I do that thing of 'Um, ah, no', and then I go, 'Well, what do you think, what do you reckon?'. We'll sit on it for a while and eventually come to an agreement. Or I'll put something forward and Alana will say, 'I don't think that's right' and give the argument for that. And I will either go, 'Oh yeah I get that, yep cool, let's go with that' or 'No'. Then I'll put my argument forward. There was definitely this collaboration on the story-writing but also the ideas - throwing things out there and thinking 'yep' or 'no' or 'we'll talk it out'.

Alana: I think the foundation of the theatre-making artform is play. And one of the things is that you can be really flippant and say, 'Oh we just laughed a lot and told each other filthy jokes', which is actually true! But the best possible collaborations push you as an artist to be more than you are by yourself. And I've got to say, hand on heart, that's what I've really loved about working with Ursula - for so many reasons, but mostly because her instincts, after 20 years of performing, are just really, really sharp. She'll not necessarily be able to say why 
something doesn't work - and I'll be like, 'that's ok, let's just move on.' But she'll be like 'stop' and make me examine it. Or I will say something really outrageous and think, 'I can't say that'. And Ursula will say, 'No we'll bring that in', or the opposite. Some of the stuff is incredibly vulgar and we're like, 'Can we really do that?' It's because we work together as a unit that we can say, 'Let's go for it'. I do think that's a really important thing to talk about in this seminar on collaboration. Collaboration does push you as an artist to be more open than you ever thought you could be. And that's been an absolute revelation for me.

Ursula: Absolutely. I don't know whether it's me. As a black woman, we have our censor on a lot. So, when there's a lot of play, there's also a lot of 'I think I can do a better joke than that'. I'll top it and Alana will come and top that. And we'll go, 'Can we do that? Yeah, so let's put it in and see how we go. We can always take it back. We can always pull it back'. We had permission to write what we wanted to write, and be as vulgar as we wanted, and as angry as I wanted. Because you know, the fear of the 'angry black woman', oh my god, 'the angry black woman'. The whole point was that I want people to see the angry black woman - and the reasons behind why she's the angry black woman. We're not just angry for nothing. Yeah, it was lovely to have that little play, Alana. It was definitely a lot of fun. More fun than stressful [laughter].

Alana: Could you talk more about that angry black woman? We did an interview and there was a male journalist who said to us, 'Oh, I didn't like Barbara for the first 40 minutes'. And we were, like, 'Oh, that's really interesting, cause we don't care' [laughter]. And I think that the collaborative unit made us able to say that together. It's about being inured to years of knowing that you've got to get the audience to be with you - and wanting them to go with you. But because we were together, we pushed our nerve on what audiences might go with. And it was like they could feel we were pushing them. Can you talk about that feeling of not having permission to be angry, or to be disliked, Urs?

Ursula: [laugh] As I was saying, I feel most of my life - you censor yourself. If you're working your way within the theatre you don't want to be seen as someone who is too outspoken or too political or, you know, too pro-feminist or whatever! Whatever that is, you don't want to be too much of something, so you pull back on what you say and how you behave around others. Which gets you somewhere. But once you get to that point, you do start to question all those things that eat away at you. For me, it's always black issues. And mainly around exposure, I guess. Not just for me, but in general.

I love the fact that my brain is running off in another direction and I love that we have something like Netflix because I get to choose the people I watch, the people that I can connect with. Because we don't get that on Australian television as much - unless we watch ABC, which is great, and SBS.

I really did feel that I'd censored myself for a lot of my life. And I just wanted to be able to speak of the things that really affected me. Not just on an emotional level but on an everyday level too. I wanted to be able to speak on that stuff and give myself that platform. I'm so fortunate to have that platform and to be able to say, 'Hey, these are things that I'm really 
passionate about, so I'm going to talk about them'. So, on a human level, and definitely when it comes to storytelling, I wanted this to be a black woman story, how she is. She's driving her own narrative and she is very flawed. And putting in place those little reasons why she is the way she is, as well.

Alana: Yeah, we talked a lot about embracing Barbara's flaws during the process. Ursula, you talked about your frustration of not playing characters who were sufficiently complex that they had their own internal flaws. You know, Ursula is, without qualification, one of the best actresses in Australia. It's appalling to see Ursula given roles where she doesn't get to play the complexity of internal problems as well as what is being done to the character.

One of the things we tried really hard to show with Barbara is that she is the author of many of her own misfortunes, but there are reasons for that. And they're complex reasons. When the play was on in Melbourne, one of the best reviews I ever read was by a woman, Carissa Lee (Inaugural Witness First Nations Emerging Critic, doing a $\mathrm{PhD}$ on Indigenous Theatre). She said that what she was seeing more and more - I've got it here to read: 'It's the embrace of the reality of a woman who's complex, who is not blameless. We've all done things we wish we hadn't. We're all human. I'm hoping the trope of the perfect female protagonist is at last buried in the past. This is real, this is us.'

We had a lot of conversations with Indigenous artists about that, didn't we, Urs? That thing of showing - for want of a better word - that you're not, she's not just a victim character. The character is an author of their own life.

Ursula: Absolutely. And interspersing within the whole piece, yeah, black issues. It was definitely one of those things we talked about constantly. There are times when I don't like Barbara myself [laughter], but it's sometimes because of what I'm used to seeing around me, and how we're meant to behave. I must say it was very cathartic to perform her, the very first season, yeah, I felt like every night I was going, 'aahh' [hands up in the air], and dumping everything there [hands down towards the floor]. So, it's nice to play a character that was very complex because a lot of the stuff over twenty-two years of performing was very much surface. It's not just a black issue. I think a lot of women characters are unthreatening when it comes to plays in general.

Alana: I think that's right - and it's slowly changing. It's really interesting because, when we started, it was seven years - six years before it got put on. And we were working away, and gradually Barbara made space for herself. She almost ploughed that furrow for herself, and I think that was an important part of the collaboration.

If you have questions specific to your interests, use the Chat function and we can try and answer them. I think it would be good for you to see this next section of the play. Are you cool with that, Urs? Do you want to say anything else?

Ursula: [looking at Chat] There's already a question that's come through, but yeah, we'll get onto that after this clip. 
[Video recording: After Barbara (Ursula Yovich) exits the stage, René (Elaine Crombie) sings Maths and science, a song about running out of tough love for her sister. Barbara returns to the stage and describes the anger, pain, and nightmare of racism, and a night that ends in a police paddy wagon. The scene ends with Barbara singing Pieces, on the heartbreak of her dying mother thinking her daughter doesn't care.]

Alana: [to Ursula] You haven't seen Elaine sing that before, huh?

Ursula: No, [smiling] it was nice [laughter].

Alana: Yeah [smiling, laughs].

Ursula: [Hands up as if to frame a shot]. It all sounds different front-on because when you're in it, it's all around you, so it's nice, yeah.

Alana: So maybe we should have some questions. Do you want to talk about the musician question [in the Chat]?

Ursula: Yeah, is it from Nicole Skeltys. [Reading]: How long did it take to write the songs?

Nicole Skeltys (audience): Hello, yes, it's me. The music was amazing and the singing was incredible, so it was very, very powerful.

Ursula: Thank you. Adm [Ventoura] and I had written a few songs prior to Alana and I starting the script but - yeah, the majority of the songs were recorded - what was it, was it over a week, Alana?

Alana: Yeah, we had three really intense days in Adm's studio. Adm was the musical director for Barefoot divas as well. One of the things you should take from this day is to keep working with people you connect with and know. It's really important because it creates a trust and a knowledge. So, recording the songs actually worked reasonably fast. It was three days we were in the studio and we wrote many of the songs. Some of them were songs that existed, that Ursula and Adm had written, and others were ones we worked out.

For instance, Look at the sun, which you heard at the beginning. I'd written these really complicated lyrics. I remember it was one of the first ones we did in the workshop. Urs picked them up and grabbed little bits out of this overwritten lyric and made it work. It really was, again, that thing of passing the laptop. It was like, 'Well here' [motion of passing a laptop] 'this is what I'll do with it' - and then Adm changed things and we worked out which bits were the chorus. So, it really is that collaborative process where anyone can have a starting point in terms of the music. What was fun for me in the studio is exactly what Ursula talked about. She'll write songs and I'm there with my little recorder [laughter]. Adm and Ursula would go 'What did we just do?' It's one of the great privileges of my life to watch Ursula pick up this lyric and start singing! She has all these amazing songs within her. I was just there, recording, and then playing it back. Then we'd do the same process Ursula talked about with the writing. 
We'd listen to it and we'd go, 'Yeah, that bit works but not this'. Do you want to take it from there, Urs?

Ursula: Alana didn't over-write too much [laughter]. It was wonderful. What you brought to the table was just wonderful; we had something to work with. Adm and I, especially Adm he's such an accomplished, amazing musician - he was able to look at something and go, 'What are we thinking in terms of where it sits within the story? Is it up tempo? Is it this?' He was able to come in with his little idea on that. And then, the way Adm and I work is, we'll play things over and over again and I will just keep riffing over a chorus.

We were really fortunate with the songs that you brought in Alana, to have stuff to work with and not have to come up with it myself. It was wonderful to have that over those three days, and go, 'Oh, let's move these lyrics around just slightly and let's cut these words out'. Yeah, it was play. It worked incredibly well with those songs. We just happened to be in a groove. I'm sure if we were trying to do another play-slash-musical it probably [laughter] wouldn't run as smoothly as it did those three days. Those three days were just a bit of magic - and great energy - happening at that point.

Nicole: Wow, you were definitely tapping into some magic there. And it looks like the speed of it - you were in the flow, as they say. Did the style of music organically come out of the melodies and the lyrics that you had in your head?

Ursula: Most of it would have come from the lyrics. Especially stuff that you didn't have music to in your head, initially. Just trying to think. That last song on the video clip, Pieces, was one I'd written for my mother. And I discussed this with, Alana: 'Do we put this in, because it fits quite perfectly there?'. And we said, 'We'll park it there to see'. It sat for a very long time, and then we said, 'You know what, let's do it'. It was a song that I wrote with another friend and Adm. So, there's a few that we pulled from our catalogue, and some that were created while we were working on the piece.

Alana: One of the things that was really important to both of us was that the songs not be like a traditional musical song in terms of explaining or extemporising the emotional moment in the play. We really wanted this to be like songs you could sing at a rock gig without any drama around it. That's why I played such a long bit of the second video recording - to show you how the play worked with the monologue and the scenes and the songs. Because it's not a traditional musical. It's a rock musical in that Ursula and Adm do perform the songs, quite often, at gigs. I only had one person say to me, 'Oh, but the songs don't really relate to the play'. And it was like, 'They do, but they relate in an emotional way'. And I do actually think that's how more contemporary musicals are working. There's a musical called Once, which is about a street musician, and again, the songs make emotional sense rather than narrative sense. And we were really, really strong about that, weren't we, Urs, in rehearsal?

Ursula: Yeah. I don't mind watching musicals, but I knew I definitely didn't want to write a musical in the traditional sense. We wanted the songs to stand on their own. The idea was for them to sit in an album on their own, without even the story. The songs stand on their own, but 
they definitely help move the story along. That's the emotional journey of the play. For me, it's like there are two stories: what you're hearing and seeing, but also what you're feeling. I can't remember the conversations that we had, but I do remember something like, 'I don't want it to be like other musicals, I definitely don't want that'. I'm not throwing shade or anything on musicals! I just knew that was not a part of who I am, as a person. I would say, I can't possibly do that.

Alana: There's a question here [in Chat] from Kelly Gardiner on collaboration as a conversation [Reading]: I wonder did you consciously make time for conversation or separate writing time, or was it a more free-flowing process?

Alana: I would describe collaboration as more than a conversation. It's three things: loyalty, instinct, and play. They're the three things you have to really privilege. I think that what's interesting to me about collaboration. For instance, Ursula and I might have lunch together and not talk about Barbara at all. But I still think that's about our collaboration. You have to get to know who the other person is. Don't you think, Urs, that we've got to know each other as humans, as spirits, as much as anything?

Ursula: Yes, just an example: this morning I'm up the road grabbing myself a coffee and Alana calls and she goes, 'Oh, are you getting a coffee?' And I go, 'Oh, can you hear the café?' and she goes, 'No, but I know you're out and about, and I know you so well' [laughter]. It's the personal relationship as well as the professional relationship that you've got to build on. I mean, you know a lot about me, Alana. I'll have my off days and I will let you know about that, and you understand. You're able to go, 'That's cool. We can come back to this later, or do you want to push through?' It's just really, really understanding each other, personally as well as professionally. And having that respect for each other. And there is a loyalty to the story, as well as each other. And a loyalty to the characters. These girls, I feel like they live in their own space outside of Alana and myself, so we treat them with love and respect.

Alana: Yeah, and also, as you said Ursula, we don't always like the characters. There's one time when René says to Barbara, 'You frustrate the shit out of me'. I think Barbara also does that to us. We thought and talked a lot about all the difficult, strong, angry women that we've known - the kind of women who have come in like a tornado. Everybody's got them in their life. Everybody's got these disrupters, and that's what Barbara is.

Alana: There's a question here [in Chat] from Felicity about the relationship between René and Barbara. We could talk about Elaine [Crombie, who plays René]. I wanted to play that scene [the second video recording], so that you would see their relationship as much as the group. Ursula and Elaine have known each other for many, many years, so we were utterly privileged to have Elaine - who's a consummate actress as well as a singer - to play René. Do you want to talk about that, Urs?

Ursula: It's one of those things I tell any young people who are still at school. I look around the classroom and say, 'These are the people you're going to work with - maybe not next year or the year after, but you're going to build connections, and the industry grows with you. The 
people you graduate with, they're the people you're going to be working with, so be nice, try and make friends'.

Elaine - I've known her for a very long time. We've done the Sunshine club together. We've lived together on four different occasions, so we know each other very well. I was watching [the second video recording] and thinking, no one younger could play these roles because they're all about owning who you are. And I don't think you get to own who you are until you're at least in your late 30s. Hitting 40, you start to go, 'Ah, this is who I am'. I was watching Elaine [in the clip] and I've seen how much she has grown, and I was getting goose bumps. So, it is about relationships, building strong relationships with people you're going to work with.

Alana: Yes. And being in it for the long haul. You know, Felicity, I sent you that list of the many Aboriginal and Indigenous artists I've had the privilege to work with. And they've taught me that you've got to stick around; you've got to be there through thick and thin; you've got to be a part of it. You can't just duck in and take. You've got to be there and contribute. One of the amazing things about Ursula, writing this role for Elaine, was that we played to Elaine's strengths. People afterwards were saying, 'How sizzling hot is Elaine?'. And we're like, 'Yeah, how long has it taken you to notice? She's smashing it, cause she's so hot!'

Alana: The way Ursula just aches - in the scene you just watched - when she is taken in the police van, and she makes that political speech. There's no artist in Australia who can stand on stage and rip an audience's heartstrings out like Ursula - so we knew that there had to be a moment where Ursula was given a chance to do that. What's great about writing for performers, and I've done it a lot, is that you play to their strengths. So, they feel that they can actually put those things across. And then, they'll go with you on the things that are unfamiliar. Isn't that right, Ursula? You need to feel, 'Oh, I can do this. This is the best of what I can do' [laughter]. Are there any other questions? I feel like we've covered most of the collaborative stuff.

Ursula: There's one more question there [in the Chat] from Bagryana Popov about how you take care of yourself in a role like Barbara.

It's really hard to look back. I find it difficult to watch myself, but I think that's just ego coming into play. Sometimes I have to give myself more space. I generally give myself two years before I look back on any work that I've done, so I cannot critique myself too much and just enjoy it for what it is. That role was hard, because - I'll be very open and honest with you - I was going through a very difficult time during that period. I'm looking at myself [now, in the video clips just screened] and I can see all of that. I could feel exactly where I was at, during that period, by just watching that piece.

Yeah [looking at the Chat question again]. 'How do you take care of yourself?' That's a hard one. I'm not sure how people can take care of themselves in performance when you're playing difficult things that are, you know, close to you, that speak to you. It can be hard. There were times when I felt it was very cathartic. At other times, it was hard. I think, for me, taking care of myself came mid-last year by stepping away from theatre. I would like to write more. Who 
knows, who knows! I think each show that you do is so different; you find ways of being able to cope, and you try and look after yourself.

So, Barbara was another piece where - well, I've never expressed how it made me feel. It was a massive mixture of feeling quite amazing, but also very fragile and vulnerable. But my superpower is being vulnerable. And at the end of the day - I hate saying that - 'At the end of the day' that's what you want. You want people to feel into you; that empathy. So that people can walk away and go, 'Jeez, yeah, I hear you.'

Ursula: [reading from the Chat] A question from Felicity: 'How has Barbara changed as a result of you having given her full reign in the show? Is she still around, and if so, what is she angry about now?' [laughter]

Ursula: Look, I think she's there in spirit [laugh]. She has changed [laugh]. And I think that comes with ageing and growing up. I'm sure I'll find something to get feisty and be angry about, who knows! She may make another appearance. Barbara is so much who I am. She's that hidden part. I find my anger is a lot quieter. It's going, 'What's worth fighting for and what's not? What can I let go of?' Because there's no point in wasting that energy?' Maybe she'll grow up! [laughter]

Ursula: [reading from the Chat] Earlier you talked about being a collaborative unit and how that empowers you to stop self-censoring. Does it also support the creation of those difficult women? Thinking about how we sometimes get pushback from audiences or readers about characters that are unexpected, angry, unreliable narrators, just too much - 'because it makes me feel uncomfortable'?

Ursula: Yes. Absolutely. We're using the words 'difficult woman', but it's just being assertive, isn't it? I mean [laugh] Barbara is difficult! But in everyday-speak, when you're assertive as a woman, you're 'difficult' or 'emotionally unstable'. I'm pretty sure most of us have experienced that at some point or another. It was interesting that it was a male journalist who felt that he didn't like Barbara for 45 minutes of the show. I found that a lot of young women really connected with Barbara and went, 'Yep, I get it'. And the older women, as well, went, 'Oh yeah, I recognise that'. Yeah, difficult. I love the word 'difficult' [laugh]. I don't know if you want to speak to that as well, Alana?

Alana: I want to point out that Ursula was doing that - standing on stage, reaching into her ribcage, pulling out her heart and throwing it on the stage - eight times a week for three weeks. Of course it has an effect on your wellbeing and who you are.

What I always used to do when I watched her was assure myself that Ursula had twenty-two years of experience and that's why she could go to those extremes - and go to that amazing place and know how to keep herself safe. Even though it rocked her around, and as Ursula said, it was one of the biggest tests, they're all big tests. That's why the derogation of the arts in this country just gets to me. The amount of work - to see Ursula perform like that on stage - it's twenty years' worth of work, to see that. I watch it and I'm in awe of her skills. And sometimes, 
with the writing we pinch ourselves and say to each other, 'Hey, did we really do that!' [laughter].

It's been amazing for us that we've won really big in Melbourne. The Helpmanns we won in Melbourne, and the Green Room awards. We got nominated in Sydney, and that's all good, but without pissing in your pocket, it's been an amazing response from Melbourne, and we've really loved that, haven't we, Urs?

Ursula: Yes. It's been wonderful. [Reading from the Chat, laughs]. 'How have family and community responded to the show?'

Ursula: We did a performance where there was an all-girl Aboriginal band from my hometown, Maningrida, up in North West Arnhem Land. They were in Sydney around the time we were performing, and we invited them to come and see us. I was nervous these girls were going to come and see me. I mean, some of them call me 'Mum' or 'Aunty' or 'Nan'. Through kinship systems, I'm related to all of them. And here they were up in the audience with English as a second language, and they're watching it, and they were blown away. Again, I think it's giving permission to shine and do what you want to do and be who you want to be. That was the feeling that I got.

I went to visit them while they were recording, a couple of days later. And it [the show] made them think differently about how they wanted to approach their music. Look, I was stoked. It was very humbling to be with them and hear how much they enjoyed it. They got up onto the stage and danced with us for the encore. And I don't think we had any other audience do that, before those girls. So, it was nice. It was the best kind of response to get.

Most of the responses I've gotten from other artists (especially in that speech about no-one understanding theft as much as a pack of thieves) were like, 'It's articulated what I was feeling'. Daniel Riley, who worked for Ilbijerri - he was a choreographer and danced with Bangarra for a while - he doesn't give too much away, but he said that, in that moment, he just wanted to stand on his seat and say, 'Yes! Yes!' I got that response a lot from my Aboriginal brothers and sisters, coming in and watching, and saying, 'I just felt like that was it. That's what needed to be said. And it was great that everyone just quietened down and listened. And they were listening very hard. It was uncomfortable, but they were listening'. It's nice to hear that from other black artists - other artists altogether. I don't know what kind of feedback you got, Alana?

Alana: I think it was Dan Wylie who said, 'In the beginning it was like stand-up comedy and he was nearly wetting himself, and then it was open-heart surgery'- which I thought was a really good description of it because that's what we wanted. We wanted to make people laugh and be with Barbara and Rene so much - and then thump them in the guts. That's what you can do when you have these amazing performers.

I have to say, the all-girl band was a really important part of it and I want to give credit to Vicki Gordon for that because that really was her vision. People loved to see the female musicians rocking out. We were really nervous the night of the first preview because we just thought, 'Oh 
is the Belvoir audience going to find this too loud?'. And then, in the middle of it, we started to realise that they were all old rockers and they were used to going to the Lansdowne for the live music. And suddenly, this whole audience was just getting more and more vocal, and by the end, they stood. We got a standing ovation on the first preview. And we thought, 'Oh that's good'. And then they stood again the next night and we thought, 'Ok, we think they're going to stand every night'. I think we did a hundred shows and we never didn't get a standing ovation. That's a testament to what audiences' reactions were.

Regarding the show that Ursula was talking about - the girls from Maningrida. There were about 40 of them - there were a lot of them - and during the encore - you could see [in the second video recording] people sitting on the stage. They just poured down onto the stage and started dancing. I thought they were going to grab the microphone from you, Urs. They were really a part of it, and that kind of response from Ursula's own countrymen was incredible, an absolutely incredible endorsement. I think it was the last preview, just before we opened.

Ursula: It was wonderful because we mentioned, within the piece, different language groups. We wanted to let people know there's over 250 different language groups here. Burrara was one of those mentioned, which was my mother's language group. You could just hear them whoohoo - yelling out [laughter]. Nice. I loved that interaction. It felt very natural and normal, because when I'm telling a story to my mates up the road, that's what you'll get back at you all the time. It felt like I was in my own home, telling a really big story.

Alana: That's one thing we haven't talked about - there was a lot of audience interaction. Ursula would tell someone sitting down the front to shift over. In that scene Ursula was just talking about - the 250 language groups - Elaine would find, usually, a young man in the front section and go over and flirt with him. One night [laughter] it got pretty interesting, didn't it, Urs! Elaine loves that audience interaction. There was quite a lot of it. Ursula would take off her earrings and people would know she was going to pretend to punch one of the patrons in this supposed beer garden or pub. Leticia Caceres, who was the director, used the audience in an incredibly inventive way. We got Best Production in the Green Room awards because of her amazing work.

Ursula: Yes, sorry, I did have something to say, but it's gone [laughter].

Alana: I think we might be close to being talked out. What do you think, Felicity? Is there any other questions?

Felicity: I think that is a wonderful note to end on. For some reason this whole conversation has made me feel very tearful! Maybe because it's our first event following the redundancies in screen studies last week. This has been a wonderful conversation to be part of when so many of us are transitioning to adjunct roles - opening up opportunities to do more research and have more conversations around these things. I'm not used to being tearful at a symposium [laughter].

Alana: That's what we do, eh, Urs? 
Felicity: It's been a privilege to have you both here and I can't thank you enough for joining us and putting up with the little [Zoom] glitches. My only regret is that we won't have time to play the last song [from Barbara] Let in the love, which would have me really reaching for the tissues [laughter]. Not because it's sentimental and over-the-rainbow but because it comes out of such a strong - fearless - place. And I think that place testifies hugely to your friendship and your collaboration and the years of work you've each done separately and together - and in collaboration with that wonderful band, The camp dogs, whom I just loved when I saw the show at the Malthouse. And of course, Elaine Crombie.

Alana: And Troy Brady - I should mention Troy is Ursula's brother (in Barbara and the camp dogs), the other Indigenous artist in the show. And the band were Michelle Vincent and Jessica Dunn, and in the first show Debbie Yap on lead and then Sorcha Alberquerque in the tour.

Felicity: I think Troy did get overshadowed [laughter]. I look back and remember him, but with those two women - Rene and Barbara - Joseph had a small but great role.

So, apart from saying thank you both, I want to say that Alana will be back this afternoon at $2 \mathrm{pm}$ and will be showing us some of her theatre work. And I'm particularly looking forward to seeing what Alana has done by going into the archives and reading 22,000 or so letters written to Lindy Chamberlain-Creighton, and also what came out of her fellowship with the Charles Perkins Centre, the show Made to measure. Nicole [Pavich] and I have had the pleasure of previewing the videos of the theatrical performances and they are riveting.

And thank you, again, Ursula and Alana, for such generosity.

[Applause] 